\title{
The quality of research on judicialization and its influence on public policies on access to medicines in Brazil: a systematic review
}

\author{
A qualidade das pesquisas sobre judicialização e sua influência \\ nas políticas públicas de acesso aos medicamentos no Brasil: \\ uma revisão sistemática
}

Pollyanna Farias Castro Pereira de Lyra (https://orcid.org/0000-0002-4163-6844) ${ }^{1}$

Dyego Carlos Souza Anacleto de Araújo (https://orcid.org/0000-0001-6631-465X) ${ }^{1}$

Genival Araújo dos Santos Júnior (https://orcid.org/0000-0002-5618-1846) ${ }^{2}$

Bárbara Manuella Cardoso Sodré-Alves (https://orcid.org/0000-0001-9875-4334) ${ }^{3}$

Elisdete Maria Santos de Jesus (https://orcid.org/0000-0002-9503-7433) ${ }^{1}$

Divaldo Pereira de Lyra Jr. (https://orcid.org/0000-0002-0266-0702) ${ }^{1}$

Lucindo José Quintans Jr. (https://orcid.org/0000-0001-5155-938X) ${ }^{4}$

\footnotetext{
${ }^{1}$ Laboratório de Ensino e Pesquisa em Farmácia Social, Departamento de Farmácia, Universidade Federal de Sergipe. Av. Marechal Rondon s/n, Jardim Rosa Elze. 49100-000 São Cristóvão SE Brasil. lepfs.ufs@gmail.com ${ }^{2}$ Centro de Ciências Exatas, Naturais e da Saúde, Universidade Federal do Espírito Santo. Alegre ES Brasil.

${ }^{3}$ Departamento de Farmácia, Faculdade de Ciências da Saúde, Universidade de Brasília. Brasília DF Brasil.

${ }^{4}$ Laboratório de Neurociências e Ensaios Farmacológicos, Departamento de Fisiologia, Universidade Federal de Sergipe, São Cristóvão SE Brasil.
}

\begin{abstract}
Patients without access to medicines often resort to the judicial system. However, no systematic review has discussed the quality of studies and the factors that may influence the access to medicines from judicialization. This study aimed to characterize the quality of research on access to judicialized medicines and their influence on public policies in Brazil. A search was conducted in the LILACS, PubMed/Medline, Scopus, and Web of Science databases using the terms "judicialization" and "medication". Two reviewers identified articles that met the inclusion criteria. Only studies written in English, Portuguese, or Spanish published from 1990 to 2018 were included. The study selection resulted in a final sample of 45 articles. The retrospective descriptive design was the most common methods, based on reports and lawsuits. A high level of heterogeneity among the studies hindered the comparison and generation of evidence capable of supporting judges' decisions based on technical-scientific criteria. This review showed that studies were heterogeneous and had low methodological quality. Moreover, they did not propose viable solutions for health managers and formulators to face the problem.

Key words Right to health, Medicines, Judicial decisions, Access to medicines, Drug costs
\end{abstract}

Resumo Pacientes sem acesso a medicamentos geralmente recorrem ao sistema judicial. No entanto, nenhuma revisão sistemática discutiu a qualidade dos estudos e os fatores que podem influenciar o acesso aos medicamentos pela judicialização. Este estudo teve como objetivo caracterizar a qualidade da pesquisa sobre acesso a medicamentos judicializados e sua influência nas políticas públicas no Brasil. Foi realizada uma pesquisa nas bases de dados LILACS, PubMed/ Medline, Scopus e Web of Science usando os termos "judicialization" e "medication". Dois revisores identificaram artigos que atendiam aos critérios de inclusão. Apenas estudos escritos em inglês, português ou espanhol publicados de 1990 a 2018 foram incluídos. A seleção do estudo resultou em uma amostra final de 45 artigos. $O$ desenho descritivo retrospectivo foi o método mais comum, com base em relatos e ações judiciais. Um alto nivel de heterogeneidade entre os estudos impediu a comparação e a geração de evidências capazes de apoiar as decisões dos juizes com base em critérios técnico-científicos. Esta revisão mostrou que os estudos eram heterogêneos e apresentavam baixa qualidade metodológica. Além disso, não propuseram soluções viáveis para gerentes e formuladores de saúde enfrentarem o problema.

Palavras-chave Direito à saúde, Medicamentos, Decisões judiciais, Acesso a medicamentos, Custos com medicamentos 


\section{Introduction}

From the late 1980s, many countries in Latin America introduced universal health coverage ${ }^{1}$. In the context of universality, access to medicines is a fundamental human right and results from the interaction of a complex network composed of patients, pharmaceutical industries, regulatory agencies, health systems, and healthcare services ${ }^{2}$. However, access to high-cost medicines does not always promote significant benefits to the patient probably because of little robust evidence in which these choices are based ${ }^{3}$.

In Latin America, the worsening of the economic and political crisis has threatened the individual and collective rights of current public policies. Consequently, when access to medicines is prevented, patients have resorted to lawsuits to ensure this fundamental right ${ }^{1,4}$. This phenomenon, known as "judicialization of access to medicines", has emerged in several middle-income Latin American countries, such as Argentina, Brazil, Chile, Colombia, Costa Rica, Peru, and Uruguay $^{1,5-8}$. Paradoxically, judicialization has caused positive and negative effects on the access of medicines, affecting both the population and the health and justice systems ${ }^{2,5}$.

In several countries, judicial decisions often ignore public policies and national essential drug lists, leading to a significant increase in investments related to the incorporation of health technologies ${ }^{1,9}$. Furthermore, national judicial decisions have not usually agreed with international standards and jurisprudence, which creates discrepancies in the adoption of specific medicines comparing to other countries ${ }^{8,9}$. Nowadays, previous systematic reviews reported that almost all studies on judicialization in world were conducted in Brazil, but these studies did not address the quality of studies and the details of aspects that could influence public policies and access to medicines $^{3,4,10-12}$.

In light of this gap, studies should broaden the discussion on the different dimensions of judicialization to suit as a foundation to the formulation of new Brazilian policies on access to medicines, as well as the incorporation of innovative, economic, and necessary technologies. Thus, this study aimed to characterize the quality of research on judicialization and its influence on public policies on access to medicines in Brazil.

\section{Methods}

\section{Data sources and searches}

A systematic literature review was carried out to identify empirical studies involving access to medicines through different aspects of the phenomenon of judicialization. A comprehensive search was conducted in PubMed/Medline, Scopus, LILACS, and Web of Science databases. The literature search included studies published from 1990 to 2018, considering that Brazilian health system was first regulated in 1990. This review followed the adapted version of Preferred Reporting Items for Systematic Reviews and Meta-Analyses guidelines (PRISMA) ${ }^{13}$.

Search strategies were developed using $\mathrm{MeSH}$ and DeCS terms as well as text words related to the study, such as judicialization, judicial decisions, medication, pharmaceutical preparations, and Brazil. Searches were adapted to the syntax and subject headings of each database. The full search strategy can be found in Chart 1 . The inclusion and exclusion criteria were described in a flow diagram.

\section{Eligibility}

The screening process was conducted in three stages (title, abstract, and full-text screening) by two independent researchers that removed duplicates and examined the studies. At all stages, a third reviewer resolved any case of disagreement. Titles and abstracts were analyzed considering the following inclusion criteria: (i) studies involved empirical research (quantitative or qualitative); (ii) studies were written in English, Portuguese, or Spanish; (iii) studies only involved the judicialization of medicines in Brazil. Articles without abstracts and full text available were excluded.

\section{Data Extraction}

Data extraction was performed by two researchers using a standard form that collected: study setting, duration, sample size, participants, plaintiff, judicial decision cost, judicial decision approval, the existence of scientific advisory committees, prescription origin, number of prescription drugs, the main therapeutic indications, if the prescription drugs were present in official drug lists, unregistered medicines, off-label medicines, main findings, and the study's limitations. The extracted data were divided into (i) the main characteristics of the studies and (ii) the influ- 
ence of judicialization legal aspects on the access of medicines. Expenditures were calculated in US dollars (the exchange rate in Brazil on 30 May 2018, 3.74 Brazilian reais per dollar).

\section{Quality of research}

No validated scale was found to assess the quality of articles with the characteristics of judicial studies, therefore we used Strengthening the Reporting of Observational Studies in Epidemiology (STROBE), the most appropriate form for reporting observational studies ${ }^{14}$.

\section{Results}

After the selection process, 45 studies met the inclusion criteria. The study selection process is shown in a flow diagram (Figure 1), according to the PRISMA standards ${ }^{14}$.
The main characteristics of the studies can be found in the SciELO depository on the link https://doi.org/10.48331/scielodata.Z2JQUT. All included studies were published from 2007 to 2018. Quantitative methods, such as retrospective descriptive design, were adopted in 40 studies ( $89 \%)$ while only one study (2\%) used a qualitative approach and four (9\%) used mixed methods (qualitative and quantitative analyses). Regarding the study sample, most studies used documents (reports and lawsuits) while five studies used participants (doctors, patients, lawyers, public managers, and pharmaceutical industries $)^{7,15-18}$. Furthermore, the sample size varied from 10 to 56,345 judicial decisions, being mostly defined for convenience.

Of the selected articles, 31 (69\%) reported the granting of actions where most judges granted favorable decisions without considering the technical-scientific criteria. Importantly, some of these decisions were not final and

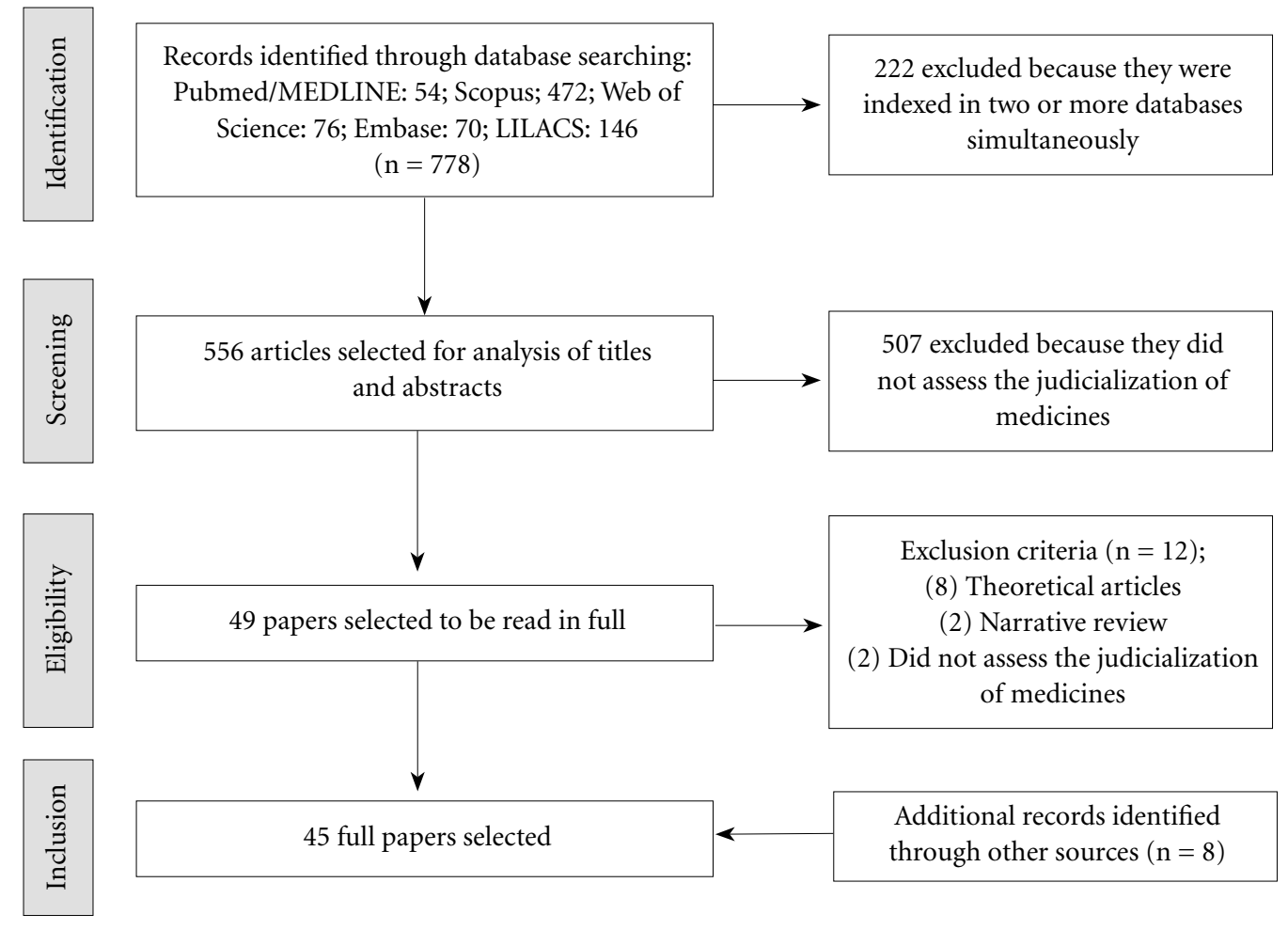

Figure 1. Flowchart with study steps adapted from Preferred Reporting Items for Systematic Reviews and MetaAnalyses (PRISMA). 
Chart 1. Search strategy to assess judicialization of medicines syntax by databases, 1991-2018.

\begin{tabular}{|c|}
\hline LILACS $=146$ \\
\hline 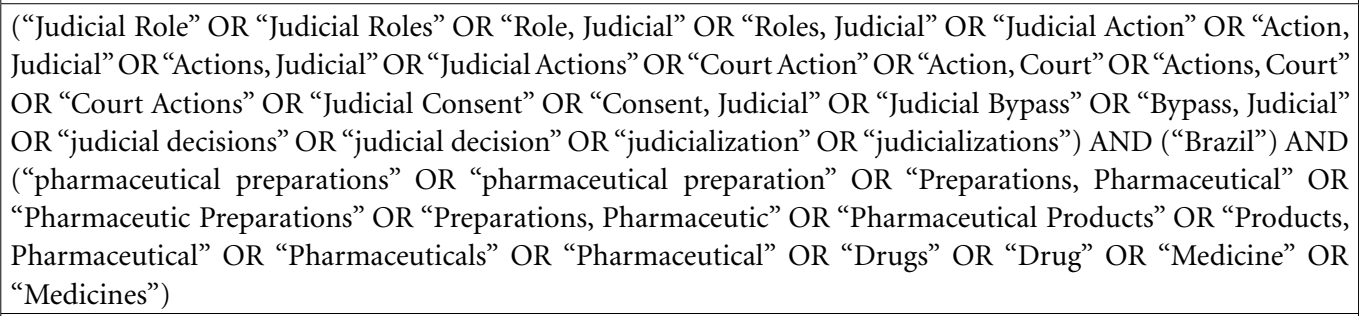 \\
\hline PUBMED = 54 \\
\hline 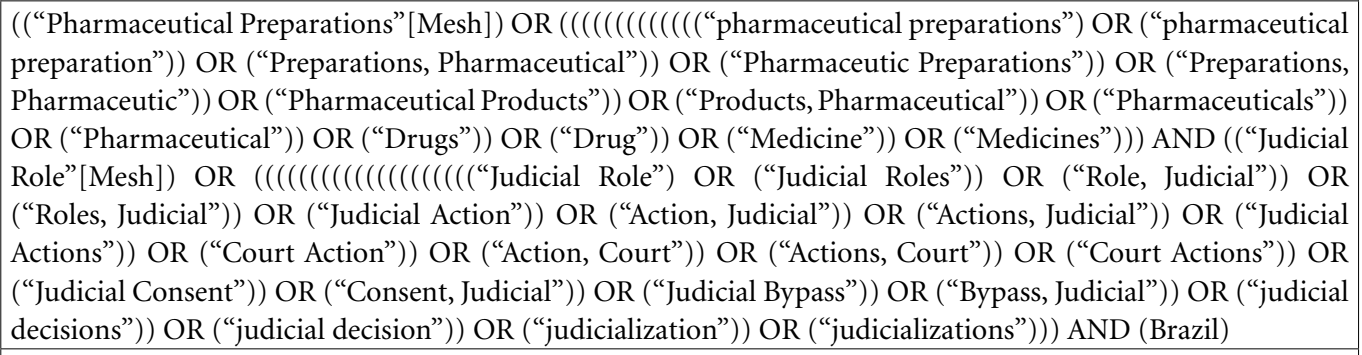 \\
\hline SCOPUS $=472$ \\
\hline 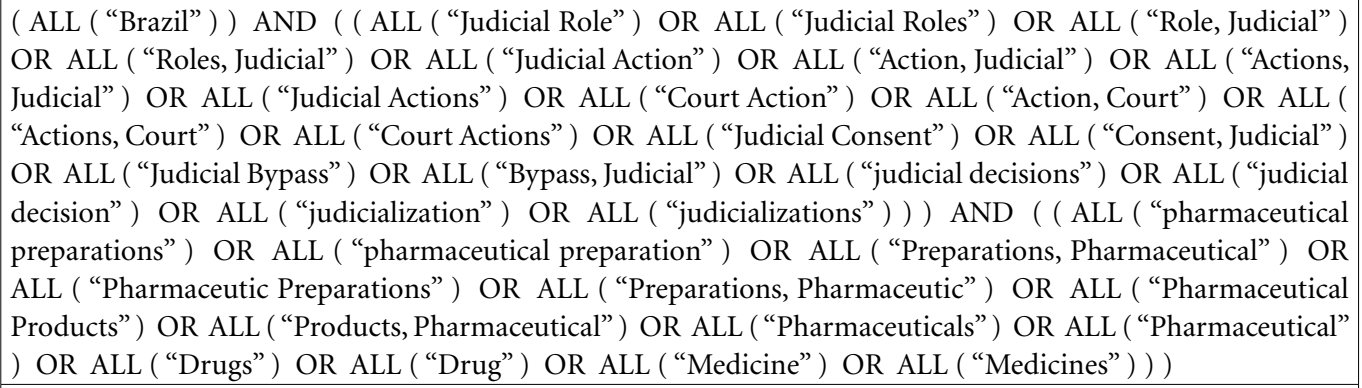 \\
\hline WEB OF SCIENCE $=76$ \\
\hline 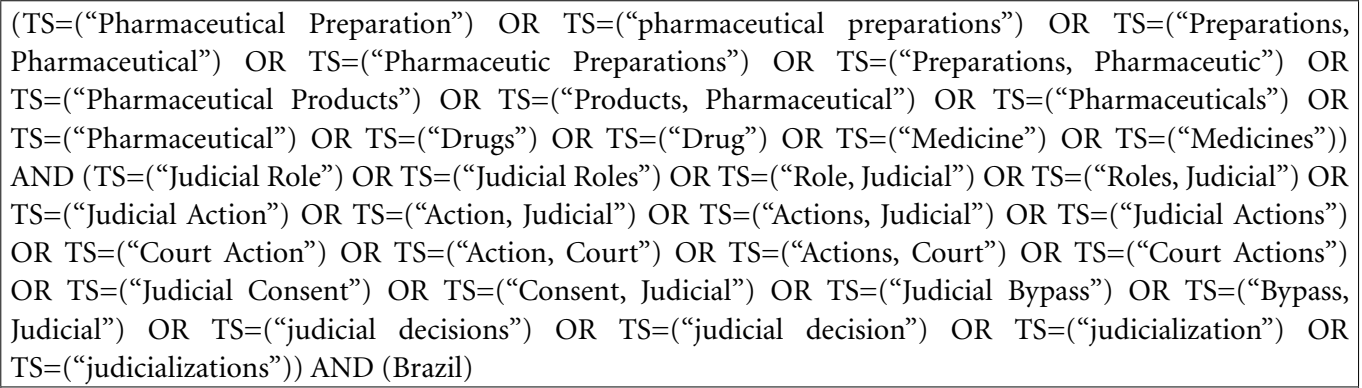 \\
\hline EMBASE $=70$ \\
\hline $\begin{array}{l}\text { ('judicial role' OR 'judicial roles' OR 'role, judicial' OR 'roles, judicial' OR 'judicial action' OR 'action, } \\
\text { judicial' OR 'actions, judicial' OR 'judicial actions' OR 'court action' OR 'action, court'OR 'actions, court' OR 'court } \\
\text { actions' OR 'judicial consent' OR 'consent, judicial’ OR 'judicial bypass' OR 'bypass, judicial' OR 'judicial } \\
\text { decisions' OR 'judicial decision' OR 'judicialization' OR 'judicializations') AND ('pharmaceutical preparations' } \\
\text { OR 'pharmaceutical preparation' OR 'preparations, pharmaceutical' OR 'pharmaceutic preparations' OR } \\
\text { 'preparations, pharmaceutic' OR 'pharmaceutical products' OR 'products, pharmaceutical' OR 'pharmaceuticals' } \\
\text { OR 'pharmaceutical' OR 'drugs' OR 'drug' OR medicine' OR 'medicines') AND ('Brazil') }\end{array}$ \\
\hline
\end{tabular}

Source: Authors' elaboration.

would fit appeal7,15-19-44. Regarding the expenditures on lawsuits, in 22 studies (49\%) the costs ranged from US $\$ 9,653.62$ to US $\$ 1,545$ billion $^{17-19,22,24,26,29,30,33-35,38,41,42,44-51}$. Although the National Council of Justice (2010) recommends the implementation of scientific advisory com- 
mittees (with doctors and pharmacists), only six studies (13\%) mentioned its existence or importance ${ }^{25,31,39,40,50,52}$.

Among the selected studies, only six (13\%) had expert advice from doctors or pharmacists to evaluate the request for off-label drugs ${ }^{28,30,38,39,47,50}$. Almost half of the studies $n=22(49 \%)$ analyzed the drug indication not approved by national or international regulatory agencies $^{16,19,22,23,26,28,30,33,34,37,39,40,41,44,46,49,50,51-55}$.

In this review, 17 studies $(38 \%)$ reported the prescription origin, most from the public sector $7,22,23,27,29,30,33,35,40,41,44,46,48,52,53,56,57$ and 27 studies $(60 \%)$ reported the lawsuit age $\mathrm{nt}^{7,9,16,17,19,22-25,27,33-38,40,41,43,44,46,48,52,53,55-57}$.

Moreover, a total of 24 studies (53\%) evaluated the existence of judicial decisions related to unlicensed drugs in the coun$\operatorname{try}^{9,16,19,22,23,26,28,31,33,34,37,38,40-42,44,46,49,50-55}$. In 26 articles (58\%), the medicines in judicialization were out of official essential drug lis ts $^{7,19-23,26,28,31-34,37-41,44,46-48,50-52,55,57}$. Differently, 28 studies $(62 \%)$ discussed the causes of the judicialization of medicines on official essential drug lists that were not available to patien ts $^{7,9,15,20-23,26,28,31-34,38-41,44,46-48,50-52,54-57}$.

A study showed that the time for granting preliminary injunctions can be accelerated depending on legal procedures (i.e. instance) or clinical variables (i.e. disease severity and risk of death) ${ }^{26}$. Etanercept and Adalimumab (control of rheumatoid arthritis) were mentioned in 18 studies $(40 \%)^{9,20,21,23-25,28,30,31,34,35,38,39,44,46,49,51,56}$. These studies have been requested from one to 91,931 medicines.

Finally, seven studies (15\%) suggested the probable existence of close links between lawyers, doctors, and the pharmaceutical industry to include certain drugs on official lists as well as the existence of evidence submitted to the Brazilian government regarding the monopoly of judicialized purchase of high-cost medicines ${ }^{20,24,26,30,33,55,56}$.

Regarding the quality of the report of the studies, we observed that most studies did not include some information, such as specific aims, pre-existing hypotheses, potential sources of bias, limitations, and external validity of the study results (Table 1).

\section{Discussion}

All studies were published after 2007, which is corroborated by five reviews that highlight the highest number of publications on access to medicines for legal actions ${ }^{4,10-12,58}$. Although studies carried out in other countries have shown that several factors have prevented universal access, such as economic growth, rapid population aging, higher incidence and prevalence of non-communicable diseases, pressure in the pharmaceutical industry and low efficiency of the health system, the judicialization of medicines in countries with universal health systems, like Brazil, have increased. Thus, investments in the quality of scientific literature should be made to support health policymakers in the planning of access to medicines ${ }^{1,4-6,9,58-66}$.

Previous studies ${ }^{3.4,10-12,58}$ show that Brazil has the largest scientific production on phenomena of judicialization of health and access to medicines. This review showed that the multifaceted nature of this theme covers different areas of knowledge, such as health law, human rights, sociology, and public health with a strong influence on public policies. This variety promotes heterogeneity of aims and methodologies, hindering data comparison, and generalization of results ${ }^{2,10}$.

In the studies, it is possible to note the confusion in the discussions about the differences of universal health coverage versus the universal health system, so it is essential to know the characteristics and nuances of the two models to identify possibilities and threats to the consolidation of Brazilian Unified Health System ${ }^{67}$. Moreover, different quantitative methods such as retrospective chart reviews and mailed surveys were used despite their simplicity and the low level of evidence ${ }^{8}$. Therefore, pre-post interventional studies are needed to measure the effectiveness of the strategies to improve access and to meet clinical and economic needs ${ }^{12}$. These results can serve as scientific evidence for more coherent planning able to tend to individual demands without harming the collective ones.

The sample size and participants varied widely in the articles, probably due to the convenience sampling, the study duration, and, in many cases, to the participants and the selected therapeutic class. Such data are corroborated by previous reviews $^{8,10}$ that reported the high insufficiency of records is in the health system (at the federal, state and municipal levels), in the competent legal information, as well as in the private sector of health plans in Brazil. A convenience sample found in the selected studies is a significant bias because it may induce the stakeholders to make inappropriate choices, to incorporate unessential technologies, and to formulate policies divergent to the people's needs. Consequently, it is neces- 
Table 1. Items in the reports of the studies included in the review.

\begin{tabular}{|c|c|c|c|}
\hline & Item No & Recommendation & n (\%) \\
\hline $\begin{array}{l}\text { Title and } \\
\text { abstract }\end{array}$ & 1 & $\begin{array}{l}\text { Indicate the study's design with a commonly used term in the title or the } \\
\text { abstract. Provide in the abstract an informative and balanced summary of } \\
\text { what was done and what was found }\end{array}$ & $44(97,8)$ \\
\hline \multicolumn{4}{|c|}{ 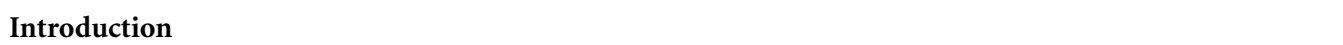 } \\
\hline $\begin{array}{l}\text { Backgroun- } \\
\text { d/rationale }\end{array}$ & 2 & $\begin{array}{l}\text { Explain the scientific background and rationale for the investigation being } \\
\text { reported }\end{array}$ & $42(93,3)$ \\
\hline \multirow[t]{2}{*}{ Objectives } & 3 & State specific objectives & $8(17,8)$ \\
\hline & & Prespecified hypotheses & $3(6,7)$ \\
\hline \multicolumn{4}{|l|}{ Methods } \\
\hline Study design & 4 & Present key elements of study design early in the paper & $37(82,2)$ \\
\hline Setting & 5 & $\begin{array}{l}\text { Describe the setting, locations, and relevant dates, including periods of } \\
\text { recruitment, exposure, follow-up, and data collection }\end{array}$ & $42(93,3)$ \\
\hline Participants & 6 & $\begin{array}{l}\text { (a) Cross-sectional study-Give the eligibility criteria, and the sources and } \\
\text { methods of selection of participants }\end{array}$ & $17(37,8)$ \\
\hline Variables & 7 & $\begin{array}{l}\text { Clearly define all outcomes, exposures, predictors, potential confounders, } \\
\text { and effect modifiers. Give diagnostic criteria, if applicable }\end{array}$ & $33(73,3)$ \\
\hline $\begin{array}{l}\text { Data sources/ } \\
\text { measure- } \\
\text { ment }\end{array}$ & 8 & $\begin{array}{l}\text { For each variable of interest, give sources of data and details of methods of } \\
\text { assessment (measurement). Describe comparability of assessment methods } \\
\text { if there is more than one group }\end{array}$ & $41(91,1)$ \\
\hline Bias & 9 & Describe any efforts to address potential sources of bias & $7(15,6)$ \\
\hline Study size & 10 & Explain how the study size was arrived at & $31(68,9)$ \\
\hline $\begin{array}{l}\text { Quantitative } \\
\text { variables }\end{array}$ & 11 & $\begin{array}{l}\text { Explain how quantitative variables were handled in the analyses. If applica- } \\
\text { ble, describe which groupings were chosen and why }\end{array}$ & $38(84,4)$ \\
\hline $\begin{array}{l}\text { Statistical } \\
\text { methods }\end{array}$ & 12 & $\begin{array}{l}\text { Describe all statistical methods, including those used to control for } \\
\text { confounding. Explain how missing data were addressed. Cross-sectional } \\
\text { study_-If applicable, describe analytical methods taking account of } \\
\text { sampling strategy }\end{array}$ & $23(51,1)$ \\
\hline \multicolumn{4}{|l|}{ Results } \\
\hline Participants & 13 & $\begin{array}{l}\text { Report numbers of individuals at each stage of study-eg numbers } \\
\text { potentially eligible, examined for eligibility, confirmed eligible, included in } \\
\text { the study, completing follow-up, and analysed }\end{array}$ & $17(37,8)$ \\
\hline $\begin{array}{l}\text { Descriptive } \\
\text { data }\end{array}$ & 14 & $\begin{array}{l}\text { Give characteristics of study participants (eg demographic, clinical, social) } \\
\text { and information on exposures and potential confounders }\end{array}$ & $43(95,6)$ \\
\hline $\begin{array}{l}\text { Outcome } \\
\text { data }\end{array}$ & 15 & Report numbers of outcome events or summary measures & $31(68,9)$ \\
\hline Main results & 16 & $\begin{array}{l}\text { Give unadjusted estimates and, if applicable, confounder-adjusted } \\
\text { estimates and their precision (eg, 95\% confidence interval). Make clear } \\
\text { which confounders were adjusted for and why they were included. Report } \\
\text { category boundaries when continuous variables were categorized. If } \\
\text { relevant, consider translating estimates of relative risk into absolute risk for } \\
\text { a meaningful time period. }\end{array}$ & $44(97,8)$ \\
\hline $\begin{array}{l}\text { Other analy- } \\
\text { ses }\end{array}$ & 17 & $\begin{array}{l}\text { Report other analyses done-eg analyses of subgroups and interactions, } \\
\text { and sensitivity analyses }\end{array}$ & $8(17,8)$ \\
\hline \multicolumn{4}{|l|}{ Discussion } \\
\hline Key results & 18 & Summarise key results with reference to study objectives & $44(97,8)$ \\
\hline Limitations & 19 & $\begin{array}{l}\text { Discuss limitations of the study, taking into account sources of potential } \\
\text { bias or imprecision. Discuss both direction and magnitude of any potential } \\
\text { bias }\end{array}$ & $20(44,4)$ \\
\hline $\begin{array}{l}\text { Interpreta- } \\
\text { tion }\end{array}$ & 20 & $\begin{array}{l}\text { Give a cautious overall interpretation of results considering objectives, } \\
\text { limitations, multiplicity of analyses, results from similar studies, and other } \\
\text { relevant evidence }\end{array}$ & $42(93,3)$ \\
\hline $\begin{array}{l}\text { Generalisa- } \\
\text { bility } \\
\text { Other informa }\end{array}$ & ation & Discuss the generalisability (external validity) of the study results & $9(29,0)$ \\
\hline Funding & 22 & $\begin{array}{l}\text { Give the source of funding and the role of the funders for the present study } \\
\text { and, if applicable, for the original study on which the present article is based }\end{array}$ & $16(35,6)$ \\
\hline
\end{tabular}


sary to organize and use more structured sources of information, allowing the selection and standardization to make real comparisons that serve as a guide for health managers in decision making about access to medicines.

Most studies reported that lawsuits were favorable to plaintiffs. This can indicate the fragility of the systems in access to health services, failures in the planning of public policies and the lack of technical knowledge of the judiciary system regarding to compliance with the guidelines of the public health system, the National Medicines Policy and the Policy National Pharmaceutical Services. The phenomenon of judicialization is driven by a widespread and often desperate patient demand, induced by pharmaceutical industries and physicians' prescriptions, and facilitated by public and private lawyers along to the judges' blind interpretation of the constitutional right to health ${ }^{7,68}$. The literature affirms that judicialization can be pejorative because it is rooted in the medicalization of life, which refers to the unnecessary use of drugs, more expensive medicines and sometimes not provided by health systems ${ }^{66,69}$. Studies that confront medicalization and judicialization can raise subjective aspects of this phenomenon and its influences on people and the health system. Moreover, new studies should focus on the positive aspects of judicialization, generating evidence of the real demands, and suggesting ways to monitor the use of judicialized drugs. Such evidence would enable important reflections on the risk-benefits of greater access to pharmacotherapy.

Several selected studies have suggested the existence of close links between lawyers, physicians, and the pharmaceutical industry, impairing the principle of equity ${ }^{20,22,24,26,30,33,61}$. Such links should be identified and limited, encouraging the most positive aspect of the judicialization, which is to identify gaps in assistance and access to public health policies to increase visibility to lawsuits and provide a range of solutions ${ }^{20,22,24,26,30,33}$. Therefore, investments should aim at studies that deepen the existence of these shady relationships and their direct and indirect influence on the right to health to guarantee access to medicines.

In this review, a higher frequency of favorable decisions was observed, disregarding the technical-scientific criteria and government official essential drug lists. Other studies showed a high success rate of the litigant against the health systems because the judges deferred decisions for the supply of medicines to guarantee the individuals' constitutional rights ${ }^{1,8,69}$. Moreover, de- pending on the judicial instance and the disease, the time for the granting of preliminary injunctions is short and does not provide conditions for pharmaceutical services to appeal ${ }^{25}$. When judges disregard public policies to meet the needs of a few people, they may create inequality in the system, harming most of the population ${ }^{11}$. Hence, magistrates should be sensitized to use scientific evidence to make decisions and health managers should create spaces to discuss indicators for the inclusion of new health technologies ${ }^{8}$.

The high frequency of judicial requests for non-standardized medicines is related to the lack of therapeutic alternatives offered by the healthcare system, lack of technical information on the legal assessment of these claims, delay of public policies and the need to incorporate new pharmaceutical technologies ${ }^{52,31}$. It is relevant to highlight that essential drug list does not limit healthcare delivery, constrains health professionals' autonomy, interfere with pharmaceutical markets, or reduce the access of medicines ${ }^{60}$. Considering this, actions to prevent the use of non-standard drugs should be taken. Some examples are the investments in systematic updating of the lists of medicines, the prioritization of an evidence-based drug selection, as well as the promotion of new pharmacotherapeutic options to prescribers and dispensers ${ }^{59,71-73}$.

Some European countries have judicial bodies specialized in healthcare or public health, so the litigants go to courts only when decisions are unreasonable or violate human rights ${ }^{73}$. These bodies could clarify the political, social, ethical, legal, and sanitary aspects of the access of medicines to the actors involved (i.e. judges, health professionals, managers, civil society associations, public prosecutor's office, and public defenders). Therefore, the patients' rights could be assured without disregard the scientific evidence. Based on international examples, Brazilian courts could be encouraged to create permanent scientific advisory committees, with health experts that would rise scientific evidence to support their judicial decisions ${ }^{8,62,74}$. When such committees exist, health professionals generally do not receive feedback on clinical outcomes after judges' decisions. Robust studies should be carried out to assess whether the recommendations of the technical-scientific committee result not only in more access to medicines, but also in the effectiveness of medicines.

Although the National Council of Justice suggests the adoption of some measures, including the creation of scientific support committees 
with doctors and pharmacists, most Brazilian states have not yet complied with this recommendation $^{39,74}$. In addition, there is still little evidence that magistrates effectively demonstrate adherence to such regulatory attempts. We do not know if the legal system has considered the technical recommendations to incorporate new technologies already available in the Brazilian Unified Health System. This scientific support could help judges, prosecutors, and other representatives of the judiciary to assess clinical and budgetary issues raised by the parties in health-related actions, ensuring greater cost-effectiveness in cases of judicialization of medicines ${ }^{7,76}$. However, the lack of these committees influences the management of pharmaceutical services since several judicialized drugs of the included studies were added to the official essential drug lists to expand access, but with a considerable increase in health budgets.

Several studies in this review carried out an economic evaluation of the impact of judicial demands on the health system. In the case of AIDS, the treatment cost per patient has increased because of the civil society groups who use the rhetoric of human rights and antidiscrimination to promote an agenda of access to medicines ${ }^{45}$. In countries where health coverage is universal, economic assessments can avoid waste, simplify financial resources, and provide specific medicines to those who need them (principle of equity) $)^{8,65,77}$. In Brazil, literature about the economic effect of the judicialization of medicines has risen recently, but the heterogeneity of studies limits the comparison of publications, as well the strategies to optimize the actions s, $^{71,72,78-80}$.

In this review, judicialized medicines for the treatment of chronic diseases, autoimmune, and rare genetic diseases represented the greatest impact on the budget of public health poli$\operatorname{cies}^{24,26,30,33,41,42,45,46,54,80-82}$. Although many drugs are well tolerated and achieve goals of remission, low activity or control of these diseases, the main causes of the evolution of expenditures are the preferences of prescribers and the success of judicial demands, without considering the cost-effectiveness of these medicines ${ }^{75,83-85}$. The articles usually only mentioned expenditures and growth trends, suggesting the need for greater financial control of health policies ${ }^{78-80}$. However, a deeper pharmacoeconomic analysis still lacks ${ }^{8,72,80}$. Such data may indicate that the guarantee of access must be rationalized, so that future studies can focus on the longer monitoring of the cost-effectiveness of medicines, carrying out more robust analyzes on their impact on health policies and action planning.

Population aging may explain why long-term medications, especially those for cancer treatment, are the most requested medicines $\mathrm{s}^{23,39}$. According to literature, providing access to novel high-cost medicines for prevalent chronic conditions poses a growing ethical and economic challenge for policymakers in countries at all income levels ${ }^{13,79.80}$. Few studies have reported drug requests with indications not approved by regulatory agencies such as the Brazilian Health Surveillance Agency, Food and Drug Administration and European Medicines Agency, and yet such requests were deferred ${ }^{39,86}$.

Based on the right to life protection, requests for drugs that are unlicensed or out of official drug lists disrupts normal pathways, creating the misconception of governments' obligation to supply these medicines ${ }^{87,88}$. In practice, the national official essential drug lists should be comprehensive, offering standardized treatment options for priority conditions of the most population, without influences of industry or personal interests ${ }^{6,89}$. The need to meet judicial demands for standardized treatment options is legitimate and often urgent since not only it shows system disorganization but also it exposes the need for effective planning of pharmaceutical services ${ }^{79,80}$. Future studies should investigate the factors that could influence this planning, such as the frequent turnover of health managers and the pressures suffered by managers to regularize the supply of medicines.

In this sense, the reorganization and planning of actions can rationalize the management of resources and favor access to medicines in the health system, mainly for the most vulnerable population. Otherwise, our findings showed that the demands are urgent while the deadlines of the execution of judicial decisions are short. This phenomenon forces the health managers to buy the judicialized medicines under penalty of paying fine, in small volumes and without bidding, which overloads the health system ${ }^{4,61,66,85}$. The findings of the selected studies also suggested that judges, when analyzing the quality-cost binomial, considered the infinite patients' needs and the finite resources of health systems, established on public policies and for the common good $^{89}$. Then, rigorous pharmacoeconomic studies must be carried out to compare the effect of these decisions on the health system.

In addition to the aforementioned methodological issues, future studies should explore 
themes that qualify the discussions on the phenomenon of judicialization of health and access to medicines, in a structured way, based on three pillars: i) understanding that the Brazilian Unified Health System has not yet reached its full potential, but it has advantages over insurance arrangements - social, private or subsidized from other countries; ii) understanding the phenomenon of the judicialization of health considering a broader framework of the role of the Brazilian judiciary in policies; and iii) understanding the phenomenon and its impact on the structure and organization of health services, whether in the public or private segment.

\section{Strengths and limitations}

The strength of this review was the discussion of the methodological quality of studies on access to judicialized medicines as well as their influence on public policies and management decisions. Besides, suggestions for an agenda for future studies considering the issues were made to qualify the empirical research. However, the main limitation of this study was the heterogeneity of the studies, a factor that complicated the comparison between variables. In addition, we did not register the systematic review protocol. Another limitation was the use of the STROBE to analyze the quality of the included articles, because although it was not recommended for this purpose, we used it as a basis for the analysis.

\section{Conclusion}

In this review, we observed that empirical investigations on access to medicines due to the phenomenon of judicialization are heterogeneous and have low methodological quality. The studies have different aims, which hinders the comparison of studies. Also, it influences the generation of strong evidence that supports judges' decision-making process based on technical-scientific criteria. The low quality of the studies is reflected in retrospective descriptive study designs, which do not analyze the impact of judicialization on the health system, the judicial system and the effectiveness of the treatments provide. In addition, these studies do not propose viable solutions for health managers and formulators to face this issue. Thus, recommendations were suggested to deepen the field of judicialization of medicines.

\section{Collaborations}

PFCP Lyra, DP Lyra Jr. and LJ Quintans Jr. were responsible for the concept of the theme. PFCP Lyra, DCSA Araújo and GA Santos Jr collected the material. PFCP Lyra, EMS Jesus, BMCS Alves, DCSA Araújo and DP Lyra Jr. analyzed the material found. PFCP Lyra, BMCS Alves, EMS Jesus, DCSA Araújo and GA Santos Jr. wrote the first draft. PFCP Lyra, DP Lyra Jr. and LJ Quintans Jr. conducted critical reviews. All authors have approved the final version of this manuscript.

\section{Acknowledgements and funding}

We thank Letícia Prates and Patrícia Aguiar for their collaboration in the first version of this manuscript. This study was funded by the Foundation for the Support of Research and Innovation of Sergipe State and Coordination for the Improvement of Higher Education Personnel. 


\section{References}

1. Cubillos L, Escobar ML, Pavlovic S, Iunes R. Universal health coverage and litigation in Latin America. J. Health Organ Manag 2012; 26(3):390-406.

2. Oliveira MRM, Delduque MC, Sousa MF, Mendonça AVM. Judicialization of health: where are heading the scientific productions to? Saude Debate [online]2015; 39(105):525-535.

3. Vitorino SMA. The Phenomenon of Judicialization and Access to High Cost Medications In Brazil: A Systematic Review Of The Literature. R. Defensoria Publ União 2020; (13):209-232.

4. Vargas-Peláez CM, Rover MR, Leite SN, Buenaventura FR, Farias MR. Right to health, essential medicines, and lawsuits for access to medicines-a scoping study. Soc Sci Med 2014; 121:48-55.

5. Vargas-Peláez CM, Rover MRM, Soares L, Blatt CR, Mantel-Teeuwisse AK, Rossi FA, Restrepo LG, Latorre MC, López JJ, Bürgin MT, Silva C, Leite SN, Farias MR. Judicialization of access to medicines in four Latin American countries: A comparative qualitative analysis. Int J Equity Health 2019; 18(1): 68.

6. Marín GM, Campiño SAJ, Tejada CMR, Castaño AB, Jaramillo JV. Acciones de tutela sobre el derecho a la salud em el municipio de Leticia, Amazonas, 20042008. Iatreia 2010; 23(4):335-343.

7. Biehl J, Amon JJ, Socal MP, Petryna A. Between the court and the clinic: lawsuits for medicines and the right to health in Brazil. Health Hum Rights 2012; 14(1):36-52.

8. Pinzón-Flórez CE, Chapman E, Cubillos L, Reveiz L. Prioritization of strategies to approach the judicialization of health in Latin America and the Caribbean. Rev Saude Publica 2016; 50:56.

9. Biehl J. Patient-citizen-consumers: judicialization of health and metamorphosis of biopolitics. Lua Nova 2016; 98(1):77-105.

10. Freitas BC, Fonseca EP, Queluz DP. Judicialization of health in the public and private health systems: a systematic review. Interface (Botucatu) 2020; 24:e190345.

11. Gomes VS, Amador TA. Studies published in indexed journals on lawsuits for medicines in Brazil: a systematic review. Cad Saude Publica 2015; 31(3):451-62.

12. Reveiz L, Chapman E, Torres R, Fitzgerald JF, Mendoza A, Bolis M, Salgado O. Litigios por derecho a la salud en tres países de América Latina: revisión sistemática de la literatura. Rev Panam Salud Publica 2013; 33(3):213-222.

13. Moher D, Liberati A, Tetzlaff J, Altman DG; PRISMA Group Preferred reporting items for systematic reviews and meta-analyses: the PRISMA statement. Ann Intern Med 2009; 151(4):264-269.

14. Von Elm E, Altman DG, Egger M. Strengthening. The Reporting of Observational Studies in Epidemiology (STROBE) statement: guidelines for reporting observational studies. Br Med J 2007; 335:806-808.

15. Carvalho MS, Leite SN. Itinerary of users of judicial access to medicines in the state of Amazonas, Brazil. Interface (Botucatu) 2014;18(51):737-748.

16. Marques SB, Dallari SG. Safeguarding of the social right to pharmaceutical assistance in the state of São Paulo, Brazil. Rev Saude Publica 2007; 41(1):101-107.
17. Trevisan LM, Nalin T, Tonon T, Veiga LM, Vargas $\mathrm{P}$, Krug BC, Leivas GC, Schwartz VD. Access to treatment for phenylketonuria by judicial means in Rio Grande do Sul, Brazil. Cien Saude Colet 2015; 20(5):1607-1616.

18. Wang DWL, Vasconcelos NP, Oliveira VE, Terrazas FV. The impacts of health care judicialization in the city of Sao Paulo: public expenditure and federal organization. Rev Adm Publica 2014; 48(5):1191-1206.

19. Araújo KEG, Quintal C. A judicialização do acesso aos medicamentos em Belo Horizonte: uma questão sobre equidade. Rev Bras Polit Publicas 2018; 8(3):212-235.

20. Boing A, Bloemer NS, Roesler C, Fernandes S. The judicialization of access to medicines in Santa Catarina State: a challenge for the management of the health system. Rev Dir Sanit 2013; 14(1):82-97.

21. Borges DCL, Ugá MAD. Conflicts and impasses in the judicialization of the supply of medicines: circuit court rulings on claims brought against the State of Rio de Janeiro, Brazil, in 2005. Cad Saude Publica 2010; 26(1):59-69.

22. Cabral I, Rezende LF. Analysis of individual lawsuits on supplying medication in São João da Boa Vista, São Paulo, Brazil. Rev Dir Sanit 2015;16(1):59-77.

23. Chieffi AL, Barata RB. 'Judicialization' of public health policy for distribution of medicines. Cad Saude Publica 2009; 25(8):1839-49.

24. Chieffi AL, Barata RCB. Legal suits: pharmaceutical industry strategies to introduce new drugs in the Brazilian public healthcare system. Rev Saude Publica 2010; 44(3):421-429.

25. Coelho TL, Ferré F, Campos Neto OH, Acurcio FA, Cherchiglia ML, Andrade ELG. Legal and health variations in drug litigation injunctions granted in $\mathrm{Mi}-$ nas Gerais. Rev Saude Publica 2014; 48(5):808-816.

26. Diniz D, Medeiros M, Schwartz IV. Consequences of the judicialization of health policies: the cost of medicines for mucopolysaccharidosis. Cad Saude Publica 2012; 28(3):479-489.

27. Diniz D, Machado TRC, Penalva J. The judicialization of health in the Federal District of Brazil. Cien Saude Colet 2014; 19(2):591-598.

28. Figueiredo TA, Osorio-de-Castro CG, Pepe VL. Evidence-based process for decision-making in the analysis of legal demands for medicines in Brazil. Cad Saude Publica 2013; 29(1):159-166.

29. Leite SN, Schaefer C, Fittkau K. Judicial litigations and social welfare: access to medicines in two towns in the Santa Catarina State, Brazil. Acta Sci 2012; 34(1):295301.

30. Lopes LC, Barberato-Filho S, Costa AC, Osorio-deCastro CGS. Rational use of anticancer drugs and patient lawsuits in the state of São Paulo, Southeastern Brazil. Rev Saude Publica 2010; 44(4):620-628.

31. Macedo EI, Lopes LC, Barberato-Filho S. A technical analysis of medicines request-related decision making in Brazilian courts. Rev Saude Publica 2011; 45(4):706-713.

32. Magalhães ASF. Role of the Judiciary of the Federal District in providing non-standardized drugas in SUS. Cad Ibero-Amer Dir Sanit 2015; 4(3):3-24. 
35. Nunes CFO, Ramos Jr AN. Judicialization of the right to health I the Brazilian Northeastern region: dimensions and challenges. Cad Saude Colet 2016; 24(2):192-199.

36. Pauli LTS. Public health policy judicial decision: interaction between political and legal system in Southern Region of Brazil. Cad Ibero-Amer Dir Sanit 2018; 7(1):310-317.

37. Pepe VLE, Ventura M, Sant'ana JMB, Figueiredo TA, Souza VR, Simas L, Osorio-de-Castro CGS. Characterization of lawsuits for the supply of "essential" medicines in the State of Rio de Janeiro, Brazil. Cad Saude Publica 2010; 26(3):461-471.

38. Pereira JG, Pepe VLE. Judicial access to medicine in Paraná: applying a methodological model of lawsuit analysis and monitoring. Rev Dir Sanit 2014; 15(2):30-45.

39. Ramos KA, Ferreira ASD. Analysis of the demand for medicines for off label use through lawsuits in the State Health Secretariat of Minas Gerais. Rev Dir Sanit 2013; 14(1):98-121.

40. Sant'Ana JMB, Pepe VLE, Osorio-de-Castro CGS, Ventura M. Essential drugs and pharmaceutical care: reflection on the access to drugs through lawsuits in Brazil. Rev Panam Salud Publica 2011; 29(2):138-144.

41. Sartori Jr D, Leivas PGC, Souza MV, Krug BC, Balbinotto G, Schwartz IVD. Court-ordered access to treatment of rare genetic diseases: Fabry Disease in the state of Rio Grande do Sul, Brazil. Cien Saude Colet 2012; 17(10):2717-2728.

42. Stamford A, Cavalcanti M. Legal on decisions access to medicines in Pernambuco, Northeastern Brazil. Rev Saude Publica 2012; 46(5):791-799.

43. Travassos DV, Ferreira RC, Vargas AM, Moura RN, Conceição EM, Marques DF, Ferreira EF. The judicialization of health care: a case study of three state courts in Brazil. Cien Saude Colet 2013; 18(11):34193429.

44. Vieira FS, Zucchi P. Distortions to national drug policy caused by lawsuits in Brazil. Rev Saude Publica 2007; 41(2):214-222.

45. Luo J, Oliveira MA, Ramos MBC, Maia A, Osorio-deCastro CGS. Antiretroviral drug expenditure, pricing and judicial demand: an analysis of federal procurement data in Brazil from 2004-2011. BMC Public Health. 2014;14:367.

46. Machado MAA, Acurcio FA, Brandão CMR, Faleiros DR, Guerra Jr. AA, Cherchiglia ML, Andrade EIG. Judicialization of access to medicines in Minas Gerais state, Southeastern Brazil. Rev Saude Publica 2011; 45(3):590-598.

47. Picolini VM, Fila JB, Alvarenga JFR, Mastroianni PC. Percent economic analysis of acquired drugs purchases through lawsuits. J Bras Econ Saude 2016; 8(2):125-131.

48. Provin MP, Leite SN, Amaral RG. Social inequalities in lawsuits for drugs. Braz. J Pharm Sci 2013; 49(3):465474.

49. Silva EM, Almeida KC, Pessôa GSC. Analysis of drug expenditure with judicialization in the Federal District, Brazil. Cad Ibero-Amer Dir Sanit 2017; 6(1):112126.

50. Vidal TJ, Moraes EL, Retto MPF, Silva MJS. The lawsuits to antineoplasic drugs: the tip of an iceberg? Cien Saude Colet 2017; 22(8):2539-2548.

51. Zago B, Swiech LM, Bonamigo EL, Schlemper Junior BR. Bioethical Aspects of Health Judicialization for drugs in 13 Municipalities in the Midwest of Santa Catarina, Brazil. Acta Bioethica 2016; 22(2):293-302.

52. Barreto JL, Pereira MT, Guimarães MCL, Penaforte TR, Formigli VLA. Perfil das demandas judiciais por medicamentos em municípios do Estado da Bahia Rev Baiana Saude Publ 2013; 37(3):536-552.

53. Chieffi AL, Barradas RCB, Golbaum M. Legal access to medications: a threat to Brazil's public health system? BMC Health Serv Res 2017; 17:499-510.

54. Karnikowski MGO, Silva KM, Salgado FXC, Novaes MRCG. Pharmacoeconomic aspects of lawsuits filed at Secretaria de Estado de Saúde do Distrito Federal. Brasília Med 2012; 49(3):170-179.

55. Leitão LCA, Silva PCD, Simões AEO, Barbosa IC, Pinto MEB, Simões MOS. Analysis of medicine procurement lawsuits in the state of Paraíba, Brazil. Saude Soc 2016; 25(3):800-807.

56. Campos Neto OH, Acurcio FA, Machado MA, Ferré F, Barbosa FL, Cherchiglia ML, Andrade EIG. Doctors, lawyers and pharmaceutical industry on health lawsuits in Minas Gerais, Southeastern Brazil. Rev Saude Publica 2012; 46(5):784-790.

57. Santos ECB, TCRS, Zanetti ML, Istilli PT, Pereira LHTR, Torquato MTCG. Health Judicialization: access to treatment for users with diabetes mellitus. Texto Contexto-Enferm 2018; 27(1):e0800016.

58. Emmerick IC, Oliveira MA, Luiza VL, Azeredo TB, Bigdeli M. Access to medicines in Latin America and the Caribbean (LAC): a scoping study. BMJ Open 2013; 3(5):e002224.

59. Bigdeli M, Laing R, Tomson G, Babar ZUD. Medicines and universal health coverage: challenges and opportunities. J Pharm Policy Pract 2015; 8(1):8.

60. Wirtz VJ, Hogerzeil HV, Gray AL, Bigdeli M, Joncheere CP de, Ewen MA, Gyansa-Lutterodt M, Jing S, Luiza VL, Mbindyo RM, Möller H, Moucheraud C, Pécoul B, Rägo L, Rashidian A, Ross-Degnan D, Stephens PN, Teerawattananon Y, 't Hoen EFM, Wagner AK, Yadav P, Reich MR. Essential medicines for universal health coverage. Lancet 2016; 389(10067):403-476.

61. Soares JCRS, Deprá AS. Dangerous Liaisons: pharmaceutical industry, patient associations and the lega battles for access to medicines. Phys J Public Health 2012; 22(1):311-329.

62. Cano LF. Estructural litigation in health: a comparative study based on cases from South Africa, Argentina, India and Colombia. Revista Facultad Nacional de Salud Publica 2015; 33(1):111-120.

63. Contesse J, Parmo DL. Access to medical treatment for people living with HIV/AIDS: success without victory in Chile. Sur Int J Human Rights 2008; 5(8):150-169. 
64. Lamprea E. The judicialization of health care: a global south perspective. Annu Rev Law Soc Sci 2017; 13:431449.

65. Hosseinpoor AR, Victora CG, Bergen N, Barros AJD, Boerma T. Towards universal health coverage: the role of within-country wealth-related inequality in 28 countries in sub-Saharan Africa. Bull World Health Organ 2011; 89(12):881-890.

66. Salamano M, Bianchi M, Galati E. Characteristics of judicialization of health in relation to drugs. Pharm Policy Law 2014; 16(34):283-287.

67. Giovanella L, Mendoza-Ruiz A, Pilar AC, Rosa MC, Martins GB, Santos IS, Silva DB, Vieira JML, Castro VCG, Silva PO, Machado CV. Sistema universal de saúde e cobertura universal: desvendando pressupostos e estratégias. Cien Saude Colet 2018; 23(6):17631776.

68. Campos Neto OH, Gonçalves LAO, Andrade EIG. The judicialization of health in the perception of physician's prescribing. Comun Saude Educ 2018; 22(64):165-176.

69. Cernadas JMC. The growing medicalization of life: Are physicians aware of the damage it causes? Arch Argent Pediatr 2012;110(6):459-460.

70. Wang D, Ferraz O. Reaching out to the needy? Access to justice and public attorneys' role in right to health litigation in the city of São Paulo. Sur Int J Human Rights 2013;10(18):158-179.

71. Mello AF, Soares LSS, Areda CA, Blatt CR, Galato D. An economic analysis of the lawsuits filed against municipality in southern Brazil. J Bras Econ Saude 2016; 8(1):39-46.

72. Paim LFNA, Batt CR, Saccani G, Guerreiro ICK. What is the cost of brand name prescriptions in the judicialization of access to medicines? Cad Saude Colet 2017; 25(2):201-209.

73. Wagner AK, Quick JD, Ross-Degnan D. Quality use of medicines within universal health coverage: challenges and opportunities. BMC Health Serv Res 2014; 14:357.

74. Perlingeiro R. Recognizing the public right to healthcare: the approach of Brazilian courts. Rev Port Sau Pub 2014; 32(2):134-143.

75. Ribeiro LM, Hartmann IA. Judicialization of the right to health and institutional changes in Brazil. J Const Res 2016; 3(3):35-52.

76. Wang D. Courts as healthcare policy-makers: the problem, the responses to the problem and problems in the responses. Direito GV Research Paper Series 2013; 75:1-59.

77. Campbell J, Buchan J, Cometto G, David B, Dussault G, Fogstad H, Fronteira I, Lozano R, Nyonator F, Pablos-Méndez A, Quain EE, Starrs A, Tangcharoensathien V. Human resources for health and universal health coverage: fostering equity and efecctive coverage. Bull World Health Organ 2013; 91(11):853-863.

78. Barbosa PB, Alves SCM. The judicialization of medications in the state of Bahia, Brazil: the numbers from 2014 to 2017. Cad Ibero-Amer Dir Sanit 2019; 8(4):45-65.

79. Batistella PMF, Ferrari RP, Girotto E, Pieri FM, Rossaneis MA, Aroni P, Haddad MCFL. Judicialização na saúde em município de grande porte. Rev Min Enferm 2019; e-1244.
80. Maduro LCS, Pereira LRL. Legal proceedings to obtain medicines in Ribeirão Preto. Rev Bioet 2020; 28(1):166-172.

81. Ferraz OLM, Vieira FS. The right to health, scarce resources, and equity: inherent risks in the predominant legal interpretation. Rev Cienc Soc 2009; 52(1):223251.

82. Aleman A, Galan AP. Impact of health technology assessment in litigation concerning access to highcost drugs. Int J Technol Assess Health Care 2017; 33(4):411-414.

83. Navarro-Millán I, Herrinton LJ, Chen L, Harrold L, Liu L, Curtis JR. Comparative Effectiveness of Etanercept and Adalimumab in Patient Reported Outcomes and Injection-Related Tolerability. PLoS ONE 2016; 11(3):e0149781.

84. Advocacy General of the Union (AGU). Legal Counsel Ministry of Health. Judicial intervention in public health: Panorama in the Federal Justice and Notes on the harvest of State Justices. Brasília: AGU; 2013.

85. Santos JBR, Almeida AM, Acurcio FA, Oliveira Jr HA, Kakehasi AM, Guerra Jr AA, Bennie M, Godman B, Alvares J. Comparative effectiveness of adalimumab and etanercept for rheumatoid arthritis in the Brazilian Public Health System. J Comp Eff Res 2016; 5(6):539-549.

86. Donovan G, Parkin L, Wilkes S. Debate \& Analysis. Special unlicensed medicines: what we do and do not know about them. Br J Gen Pract 2015; 65(641):e861-e863.

87. Teodoro CRS, Reis ALA, Godman B, Caetano R. Federal procurement of unlicensed medicines in Brazil: findings and implications. Expert Rev Pharmacoecon Outcomes Res 2017; 17(6):607-613.

88. World Health Organization (WHO). Annex 1: WHO Model List of Essential Medicines: April 2015. 19 $9^{\text {th }}$ Edition. Geneva: WHO; 2015:51.

89. De Carli P, Naundorf B. The application of the principle of solidarity in the judicialization of health based on the principles of SUS, the establishment of understanding by the Supreme Court and the trajectory of Rio Grande do Sul, Brazil. Cad Ibero-Amer Dir Sanit 2019; 8(3):112-130.

Article submitted 04/08/2020

Approved 06/11/2020

Final version submitted $08 / 11 / 2020$

Chief editors: Romeu Gomes, Antônio Augusto Moura da Silva 